University of Nebraska - Lincoln

DigitalCommons@University of Nebraska - Lincoln

To Improve the Academy

Professional and Organizational Development Network in Higher Education

1995

Teaching Improvement: Disciplinary Differences in Faculty

Opinions

Lynnda J. Emery

Follow this and additional works at: https://digitalcommons.unl.edu/podimproveacad

Part of the Higher Education Administration Commons

Emery, Lynnda J., "Teaching Improvement: Disciplinary Differences in Faculty Opinions" (1995). To Improve the Academy. 332.

https://digitalcommons.unl.edu/podimproveacad/332

This Article is brought to you for free and open access by the Professional and Organizational Development Network in Higher Education at DigitalCommons@University of Nebraska - Lincoln. It has been accepted for inclusion in To Improve the Academy by an authorized administrator of DigitalCommons@University of Nebraska - Lincoln. 


\section{Teaching Improvement: Disciplinary Differences in Faculty Opinions}

\section{Lynnda J. Emery}

Eastem Kentucky University

Improving teaching and learning at universities where faculty are rewarded primarily for research and scholarly activity is difficult. Faculty opinions about participating in teaching improvement activities at a research university were surveyed. This article presents survey results by college. Faculty opinions about incentives for participating in teaching improvement activities, promotion and tenure criteria, faculty development interests and outcomes for participating are included. Implications for faculty development are discussed.

$\mathrm{I}_{\mathrm{t}}$ is difficult to improve teaching and learning, especially at research universities, when faculty rewards are for research and scholarly activity (Aitken \& Sorcinelli, 1994; Diamond \& Adam, 1993). Nevertheless, faculty development practices are becoming commonplace and refined at many institutions (Wright \& O'Neil, 1994). Refinement of faculty development practices and targeting these practices to audiences who are most receptive may improve teaching and learning.

When discussing theories of faculty development, McKeachie (1991) expressed hope that, in the 1990's, more attention would be given to discipline-specific theories on teaching and learning. Likewise, Angelo (1989) suggested that recognizing faculty as teaching and learning experts in their disciplines and grouping faculty together 
who share similar views may be an efficient way to promote improved teaching and learning.

Additionally, based on recent research findings, Armour, Fuhrmann, and Wergin (1990) created a profile of faculty by discipline to assist faculty developers. In the present study, an in-depth survey was conducted at the University of Arkansas to ascertain faculty opinions about the following aspects of instructional improvement: (1) the relative importance of promotion and tenure criteria, (2) outcomes of participating in instructional improvement activities, (3) incentives that would encourage them to participate, and (4) interests in faculty development practices. The purpose of this article is to examine disciplinary differences among faculty by college and distinguish those responses from the majority of the faculty.

\section{Methodology}

Data were collected using a 90-item questionnaire sent to a $50 \%$ random sample of faculty at the University of Arkansas, Fayetteville. Faculty members were selected using stratified random sampling by college and rank to provide subgroup representation. After two follow-up mailings, usable questionnaires were returned by 281 (70\%) of the faculty. Because the rate of return was not $100 \%$, the profiles of the questionnaire respondents and faculty as a whole by college and rank were examined.

As shown in Table 1, respondents were representative of the faculty as a whole by college and rank. Two-thirds (65.7\%) of the respondents were tenured and $33.4 \%$ were nontenured. The age distribution of the questionnaire respondents was: 25-29 years (2.2\%), $30-39$ years $(26.2 \%), 40-49$ years $(30.5 \%), 50-59$ years $(23.3 \%)$, and 60 and older (17.9\%).

The survey instrument was based on the expectancy theory of motivation. Since 1964, this motivation theory and its revised versions have been used to explain employee motivation (Koontz, O'Donnell, \& Weihrich, 1984; Pinder, 1984; Porter \& Lawler, 1968; Vroom, 1964). In short, expectancy theory proposes that employees will be motivated by their expectancy that their actions will result in desired 


\begin{tabular}{|c|c|c|}
\hline \multicolumn{3}{|c|}{$\begin{array}{c}\text { Table } 1 \\
\text { Respondents' Profile and University } \\
\text { Faculty Profile by Percent }\end{array}$} \\
\hline Group & $\begin{array}{c}\text { Questionnaire } \\
\text { Respondents } \\
(N=281)\end{array}$ & $\begin{array}{c}\text { University } \\
\text { Faculty } \\
(N=795)\end{array}$ \\
\hline \multicolumn{3}{|l|}{ Discipline/College } \\
\hline Agriculture & 18.5 & 16.0 \\
\hline Arts \& Sciences & 34.9 & 40.0 \\
\hline Education & 18.2 & 14.3 \\
\hline Engineering & 12.1 & 11.2 \\
\hline \multirow[t]{2}{*}{ Professions } & 16.4 & 18.6 \\
\hline & $100 \%$ & $100 \%$ \\
\hline \multicolumn{3}{|l|}{ Rank } \\
\hline Professor & 43.9 & 41.5 \\
\hline Associate Professor & 23.8 & 25.7 \\
\hline Assistant Professor & 18.9 & 20.4 \\
\hline \multirow[t]{2}{*}{ Instructor } & 13.5 & 12.6 \\
\hline & $100 \%$ & $100 \%$ \\
\hline
\end{tabular}

outcomes (Koontz et al.). This survey included major factors thought to influence faculty motivation to participate in instructional improvement activities. Those factors included the relative importance of promotion and tenure criteria, outcomes of participating in instructional improvement activities, incentives that would encourage them to participate, and their interests in faculty development practices. The questionnaire was developed from the literature and from a revision process using feedback from content experts. Content experts were faculty from the colleges and faculty development experts. The questionnaire was pilot tested prior to final revision. 


\section{Findings}

The results from the faculty as a whole using the expectancy theory of motivation as a frame of reference were reported previously (Emery \& Hammons, 1991). Reported here are the disciplinary differences by college which were explored using the chi square test of association with the .05 level designated as the reference for significant difference. These disciplinary differences are reported and contrasted with majority faculty opinions.

\section{Promotion and Tenure Criteria}

Table 2 contains a rank ordered list of the criteria by perceived importance in promotion and tenure decisions. Fifty percent or more of the faculty indicated that 8 of 16 criteria (from the Faculty Handbook) would be quite or extremely important for promotion and tenure. As expected, these criteria overwhelmingly pertained to research and scholarly activity. There were significant disciplinary differences in the top-ranked 4 of 8 of these criteria.

Evidence of research, either funded or unfunded, was ranked important by $96 \%$ of the agriculture faculty. In contrast, $78 \%$ of the education faculty perceived this as important. Likewise, agriculture faculty rated publication of articles and books $(92 \%)$ and awards, including funding of research $(84 \%)$, highest. Education faculty rated the importance of these criteria at $73 \%$ and $63 \%$, respectively.

Evidence of performances, concerts, and other creative activities in the fine and performing arts was important to the $56 \%$ of the faculty who rated the item. It should be noted that differences by college were not examined because the item more directly related to arts and sciences and $64 \%$ (179) faculty marked the item "not applicable".

The eight criteria that were not considered important by a majority of the faculty pertained to teaching, service, and self-improvement. Faculty opinion was uniform except for disciplinary differences on one criterion. Evidence of service to the public through consulting or other activities in the area of academic or professional competence by the faculty member was important to $35 \%$ of the faculty. This criterion was more important to education (47\%) faculty and less important to the professions (32\%) faculty. 


\begin{tabular}{|c|c|c|c|c|c|c|c|}
\hline \multicolumn{8}{|c|}{$\begin{array}{c}\text { Table } 2 \\
\text { Percent of Respondents Listing Promotion and Tenure } \\
\text { Criteria as Important }\end{array}$} \\
\hline \multirow[t]{2}{*}{ Criterion } & \multirow{2}{*}{$\begin{array}{l}\text { All } \\
\text { Faculty }\end{array}$} & \multicolumn{6}{|c|}{ Discipline/College } \\
\hline & & $\overline{\text { Agri }}$ & A\&S & Educ & Engr & Prof & $x^{2}$ \\
\hline Research, either funded or unfunded & 86 & 96 & 86 & 78 & 79 & 91 & $26.41^{*}$ \\
\hline Publication of articles, books, other & 82 & 92 & 82 & 73 & 79 & 88 & $26.82^{\star}$ \\
\hline Awards, including funding of research & 74 & 84 & 79 & 63 & 77 & 65 & $26.34^{*}$ \\
\hline $\begin{array}{l}\text { Professional recognition, outside } \\
\text { groups }\end{array}$ & 74 & 64 & 81 & 78 & 62 & 75 & $24.32^{*}$ \\
\hline Papers at professional meetings & 65 & - & - & - & - & & 9.86 \\
\hline Performances, concerts & 56 & - & - & - & - & - & N/A \\
\hline Directing student research projects & 56 & - & - & - & - & - & 18.60 \\
\hline Technical reports on research projects & 50 & - & - & - & - & - & 15.74 \\
\hline Innovation in teaching & 44 & - & - & - & - & - & 13.37 \\
\hline Professional self-improvement & 44 & - & - & - & - & - & 4.99 \\
\hline $\begin{array}{l}\text { Teaching materials, course outlines, } \\
\text { exams }\end{array}$ & 43 & - & - & - & - & - & 13.59 \\
\hline Work in professional societies & 41 & - & - & - & - & - & 13.12 \\
\hline Service to the public, consulting & 35 & 37 & 29 & 47 & 35 & 32 & $21.71^{*}$ \\
\hline $\begin{array}{l}\text { Service; public understanding of } \\
\text { university }\end{array}$ & 27 & - & $\cdot$ & - & - & - & 16.10 \\
\hline $\begin{array}{l}\text { Participate in written or oral exams for } \\
\text { honors or graduate students }\end{array}$ & 25 & - & - & - & - & - & 12.93 \\
\hline Committee activities at the university & 23 & - & - & - & - & - & 20.30 \\
\hline $\begin{array}{l}\text { Note. Percents include extremely or qui } \\
\text { Dashes indicate that data were not repo } \\
p=.05 ; N=281\end{array}$ & ite imp & tant. $P$ & & 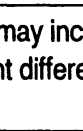 & 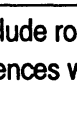 & & ected. \\
\hline
\end{tabular}

\section{Outcomes of Participation}

A majority of faculty perceived that 3 of 8 outcomes would occur to some or a great extent if they participated in instructional improvement activities (see Table 3). Overall, faculty perceived that they would become more effective (71\%), efficient (68\%), and satisfied (63\%) teachers. However, only a small percentage of faculty believed that their chances for extrinsic rewards like promotion (15\%) and salary increase (14\%) would improve. Additionally, $46 \%$ of the fac- 
ulty indicated that participation in instructional improvement would cause them to sacrifice their scholarly activity.

\begin{tabular}{|c|c|c|c|c|c|c|c|}
\hline \multicolumn{8}{|c|}{$\begin{array}{c}\text { TABLE } 3 \\
\text { Percent of Respondents' Perceived Outcomes of } \\
\text { Participation in Instructional Improvement }\end{array}$} \\
\hline \multirow[t]{2}{*}{ Outcome } & \multirow{2}{*}{$\begin{array}{l}\text { All } \\
\text { Faculty }\end{array}$} & \multicolumn{6}{|c|}{ Discipline/College } \\
\hline & & Agri & A\&S & Educ & Engr & Prof & $x^{2}$ \\
\hline Become a more effective teacher. & 71 & 85 & 62 & 82 & 77 & 67 & $26.15^{\prime}$ \\
\hline Become a more efficient teacher. & 68 & $\cdot$ & - & - & - & - & 16.08 \\
\hline Become more satisfied with teaching. & 63 & - & - & - & - & - & 19.84 \\
\hline Sacrifice my scholarly activity. & 46 & 44 & 46 & 28 & 62 & 59 & $25.02^{\star}$ \\
\hline Chair would encourage participation. & 37 & - & - & - & - & $\cdot$ & 12.73 \\
\hline Chances for promotion might improve. & 15 & - & - & - & - & - & 8.97 \\
\hline $\begin{array}{l}\text { Chances for salary increase might } \\
\text { improve. }\end{array}$ & 14 & - & - & - & - & - & 13.37 \\
\hline Colleagues might criticize participation. & & - & - & - & - & - & 7.53 \\
\hline \multicolumn{8}{|c|}{$\begin{array}{l}\text { Note. Percents include outcomes that would occur to some or a great extent. Percents } \\
\text { include rounding. } \\
\text { Dashes indicate that data were not reported when no significant differences were detected. } \\
p=.05 ; N=281 \text {. }\end{array}$} \\
\hline
\end{tabular}

Significant disciplinary differences were found in two of these items. Agriculture (85\%) and education (82\%) faculty perceived more strongly that participation in instructional improvement might make them more effective teachers whereas arts and sciences (62\%) faculty did not perceive this as strongly. Faculty also differed in their opinion on whether participation in instructional improvement would cause them to sacrifice their scholarly activity. Engineering (62\%) faculty believed this outcome would occur more strongly than education (28\%) faculty. 


\section{Incentives for Participation}

As shown in Table 4, a majority of faculty indicated that 13 of 17 incentives would encourage their participation in instructional improvement activities to some or a great extent. Predictably, salary increment $(88 \%)$, promotion $(76 \%)$, and tenure $(72 \%)$ were valued incentives. Additionally, incentives related to instruction and instructional improvement were highly rated. For example, recognition for outstanding teaching (79\%), paid released time for faculty development $(77 \%)$, and a summer grant to improve a course $(73 \%)$ were valued incentives.

Faculty opinions differed among disciplines in 6 of 13 of these incentives. Paid released time for faculty development ranged as a valuable incentive from $90 \%$ of the education faculty and to $67 \%$ of the agriculture faculty. Travel funds to attend conferences were valuable to $68 \%$ of the faculty overall. Education (86\%) and arts and sciences (76\%) attached more value to this incentive and engineering (50\%) the least value.

One course load reduction was valued by $62 \%$ of the faculty overall with significant differences noted. Education (75\%) and arts and sciences $(67 \%)$ indicated most strongly that this incentive would encourage their participation. Agriculture (46\%) attached less value to this incentive.

Four incentives were not viewed as valuable by a majority of the faculty. However, significant differences suggested that three of these incentives might be useful with specific groups. Faculty who attached more value to these incentives were: funds to obtain media and secretarial help (education $65 \%$, arts and sciences $51 \%$ ), return to industry or industry-education exchange (engineering $62 \%$, education $49 \%$ ), and opportunity to work with persons skilled in media use (agriculture $48 \%$, education $35 \%$ ).

\section{Faculty Development Interests}

Table 5 shows the percentage of faculty who indicated moderate or a great deal of interest in each instructional improvement area if time and resources were available. Although there was variation in faculty responses, over $50 \%$ of the faculty expressed interest in nine 
topics. At least one-fourth of the faculty expressed interest in $\mathbf{3 5}$ of $\mathbf{3 8}$ topics.

\begin{tabular}{|c|c|c|c|c|c|c|c|}
\hline \multicolumn{8}{|c|}{$\begin{array}{l}\text { Table } 4 \\
\text { Percent of Respondents Supporting Incentives for } \\
\text { Participation in Instructional Improvement }\end{array}$} \\
\hline \multirow[t]{2}{*}{ Incentive } & \multirow{2}{*}{$\begin{array}{l}\text { All } \\
\text { Faculty }\end{array}$} & \multicolumn{6}{|c|}{ Discipline/College } \\
\hline & & Agri & A\&S & Educ & Engr & Prof & $x^{2}$ \\
\hline Salary increment & 88 & - & - & - & - & - & 15.75 \\
\hline Recognition for outstanding teaching & 79 & - & - & - & - & - & 13.31 \\
\hline Paid released time: faculty development & 77 & 67 & 79 & 90 & 71 & 77 & $22.52^{*}$ \\
\hline Promotion in rank & 76 & - & - & - & - & - & 12.08 \\
\hline Summer grant to improve a course & 73 & - & - & - & - & - & 16.48 \\
\hline Tenure & 72 & - & - & - & - & - & 15.39 \\
\hline Travel funds to attend conferences & 68 & 60 & 76 & 86 & 50 & 58 & $25.36^{*}$ \\
\hline Funds to improve a course & 66 & - & - & - & - & - & 11.16 \\
\hline Support \& encouragement from the Chair & 62 & - & - & - & - & & 12.15 \\
\hline One course load reduction & 62 & 46 & 67 & 75 & 59 & 62 & $24.20^{*}$ \\
\hline Support \& encouragement from the Dean & 58 & $\cdot$ & - & - & $\cdot$ & - & 10.08 \\
\hline Graduate assistant & 56 & - & - & $\cdot$ & $\cdot$ & $\cdot$ & 16.35 \\
\hline Student assistant for 15 hours per week & 55 & - & - & - & - & - & 12.18 \\
\hline Funds for media and secretarial help & 47 & 46 & 51 & 65 & 35 & 32 & $27.74^{*}$ \\
\hline Faculty exchange with other universities & 46 & - & - & - & - & - & 15.65 \\
\hline Return to industry/exchange program & 35 & 29 & 23 & 49 & 62 & 42 & $34.58^{*}$ \\
\hline Work with person skilled in media use & 35 & 48 & 31 & 35 & 35 & 29 & $21.57^{\star}$ \\
\hline \multicolumn{8}{|c|}{$\begin{array}{l}\text { Note. Percents include incentives that would encourage participation to some or a great } \\
\text { extent. } \\
\text { Dashes indicate that data were not reported when no significant differences were detected. } \\
p=.05 ; N=281 \text {. }\end{array}$} \\
\hline
\end{tabular}

Significant disciplinary differences by college were found in 12 of 38 instructional improvement areas. Two of these topics, strategies for student problem-solving (62\%) and selection of effective instructional media (52\%), also received majority faculty support. Interestingly, there was no other overlap. Ten faculty development practices did not receive majority faculty support; however, disciplinary differ- 
ences suggested that these topics might be useful to specific groups. Examples of these instructional improvement interests were: using a personal computer for wordprocessing (education $63 \%$, arts and sciences 59\%), grading student performance (agriculture 52\%), professional and personal development plan or growth contract (education $58 \%$ ), group teaching strategies for seminars, labs (education $51 \%$, agriculture 50\%), writing test items (engineering 50\%), constructing examinations (professions $48 \%$ ), using a personal computer for student evaluation (education 55\%), using telecommunication media (education $43 \%$ ), teaching strategies for adult learners (education $37 \%$ ), and teaching strategies for nontraditional students (education $47 \%)$.

\section{Discussion and Implications}

Research is more important than teaching vis-a-vis the reward structure of the university (Fairweather, 1994; Wright \& O'Neil, 1994). The findings in this study also support the primacy of research in the university reward structure. For a number of faculty to engage in teaching improvement activities, incentives must be provided. If time and resources are available, faculty would participate in a variety of instructional improvement activities. Moreover, nearly threefourths of the faculty speculate that their performance as a teacher would improve if they participated.

Recent efforts to create profiles of faculty by discipline (Armour, Fuhrmann, \& Wergin, 1990) and examine disciplinary journals on pedagogy (Weimer, 1993) suggest that disciplines or colleges may be useful avenues to support faculty. The results here suggest that opinions about faculty development differ somewhat by discipline or college and merit this attention as well. Besides the nature of the disciplines making up each college, there may be other factors which contribute to the differences among colleges. These factors include different interpretations of promotion and tenure criteria by colleges, different current funding levels by colleges for incentives for participation in instructional development activities, and different existing skills by college faculty in areas in which faculty desire assistance or instruction. 


\begin{tabular}{|c|c|c|c|c|c|c|c|}
\hline \multicolumn{8}{|c|}{$\begin{array}{c}\text { Table } 5 \\
\text { Percent of Respondents Interested in Instructional } \\
\text { Improvement Areas }\end{array}$} \\
\hline \multirow[t]{2}{*}{ Instructional Improvement Area } & \multirow{2}{*}{$\begin{array}{l}\text { All } \\
\text { Faculty }\end{array}$} & \multicolumn{6}{|c|}{ Discipline/College } \\
\hline & & Agri & A\&S & Educ & Engr & Prof & $x 2$ \\
\hline Strategies for student motivation & 72 & - & - & - & - & - & $16.71^{\star}$ \\
\hline $\begin{array}{l}\text { Valid, useful, timely student rating } \\
\text { system }\end{array}$ & 69 & - & - & - & - & - & 17.90 \\
\hline Strategies for student creativity & 64 & - & - & - & - & - & 19.22 \\
\hline $\begin{array}{l}\text { Strategies for student problem- } \\
\text { solving }\end{array}$ & 62 & 69 & 51 & 76 & 64 & 64 & $22.04^{*}$ \\
\hline Lecture delivery techniques & 57 & - & - & - & - & - & 17.09 \\
\hline Strategies for student confidence & 57 & - & - & - & - & - & 14.83 \\
\hline $\begin{array}{l}\text { Use of transparencies, slides, } \\
\text { videotapes }\end{array}$ & 55 & - & - & - & - & - & 19.92 \\
\hline $\begin{array}{l}\text { Expert classroom visitation and } \\
\text { diagnosis }\end{array}$ & 54 & - & - & - & - & - & 9.20 \\
\hline $\begin{array}{l}\text { Selection of effective instructional } \\
\text { media }\end{array}$ & 52 & 67 & 54 & 61 & 35 & 34 & $25.94^{*}$ \\
\hline Group discussion techniques & 48 & - & - & - & - & - & 18.46 \\
\hline $\begin{array}{l}\text { Personal computer use for } \\
\text { wordprocessing }\end{array}$ & 48 & 33 & 59 & 63 & 32 & 39 & $28.11^{*}$ \\
\hline Planning course content & 47 & - & - & - & - & - & 11.97 \\
\hline $\begin{array}{l}\text { Faculty consult on course } \\
\text { improvement }\end{array}$ & 45 & - & - & - & - & - & 8.07 \\
\hline $\begin{array}{l}\text { Strategies for teaching large } \\
\text { classes }\end{array}$ & 44 & - & - & - & - & - & 18.77 \\
\hline $\begin{array}{l}\text { Strategies to promote value } \\
\text { exploration }\end{array}$ & 43 & - & - & - & - & - & 15.19 \\
\hline Critique of student written work & 41 & - & - & - & - & - & 18.16 \\
\hline Grading student performance & 40 & 52 & 30 & 37 & 47 & 46 & $23.37^{*}$ \\
\hline $\begin{array}{l}\text { Strategies to guide theses \& } \\
\text { dissertations }\end{array}$ & 40 & - & - & - & - & - & 20.53 \\
\hline $\begin{array}{l}\text { Plan for professional and } \\
\text { personal growth }\end{array}$ & 37 & 33 & 36 & 58 & 35 & 27 & $24.43^{*}$ \\
\hline $\begin{array}{l}\text { Strategies for group seminars and } \\
\text { labs }\end{array}$ & 36 & 50 & 32 & 51 & 32 & 18 & $27.22 *$ \\
\hline $\begin{array}{l}\text { Videotaping and critique of } \\
\text { teaching }\end{array}$ & 36 & - & - & - & - & - & 14.12 \\
\hline
\end{tabular}




\begin{tabular}{|c|c|c|c|c|c|c|c|}
\hline Writing test items & 36 & 42 & 28 & 25 & 50 & 48 & 29.48 \\
\hline Writing a course syllabus & 35 & - & - & $\cdot$ & - & - & 10.99 \\
\hline Constructing examinations & 35 & 44 & 28 & 28 & 41 & 48 & $23.51^{*}$ \\
\hline $\begin{array}{l}\text { Strategies to guide independent } \\
\text { study }\end{array}$ & 34 & - & - & - & - & . & 18.95 \\
\hline Interdisciplinary teaching & 34 & $\cdot$ & $\cdot$ & - & - & - & 16.50 \\
\hline $\begin{array}{l}\text { Personal computer for student } \\
\text { evaluation }\end{array}$ & 33 & 15 & 34 & 55 & 29 & 30 & $30.75^{*}$ \\
\hline Use of telecommunication media & 33 & 33 & 34 & 43 & 30 & 23 & $22.08^{*}$ \\
\hline Student advising and counseling & 30 & - & $\cdot$ & $\cdot$ & - & - & 3.46 \\
\hline $\begin{array}{l}\text { Preparing your own } \\
\text { transparencies }\end{array}$ & 30 & $\cdot$ & $\cdot$ & $\cdot$ & - & - & 8.95 \\
\hline Use of handouts, flipcharts & 29 & $\cdot$ & $\cdot$ & - & - & - & 10.47 \\
\hline $\begin{array}{l}\text { Select and write instructional } \\
\text { objectives }\end{array}$ & 29 & - & - & - & - & - & 18.13 \\
\hline Writing across the curriculum & 28 & - & - & - & - & - & 17.78 \\
\hline $\begin{array}{l}\text { Strategies for teaching adult } \\
\text { learners }\end{array}$ & 27 & 33 & 29 & 37 & 18 & 14 & $29.72^{*}$ \\
\hline $\begin{array}{l}\text { Strategies for nontraditional } \\
\text { students }\end{array}$ & 26 & 25 & 28 & 47 & 12 & 14 & $27.52^{\star}$ \\
\hline Team teaching & 20 & $\cdot$ & $\cdot$ & $\cdot$ & $\cdot$ & $\cdot$ & 13.85 \\
\hline Using audiorecordings & 17 & - & - & - & - & - & 17.58 \\
\hline Programmed instruction & 16 & - & - & - & - & - & 10.37 \\
\hline \multicolumn{8}{|c|}{$\begin{array}{l}\text { Note. Percent indicating moderate or a great deal of interest. Percents include rounding. } \\
\text { Dashes indicate that data were not reported when no significant differences were } \\
\text { detected. } \\
p=.05 ; N=281 \text {. }\end{array}$} \\
\hline
\end{tabular}

Examination of faculty opinions by colleges may assist faculty developers to target resources and understand perspectives of these groups. Agriculture faculty express more strongly than others that evidence of research, publication of books and articles, and awards, including research proposals, are important in promotion and tenure decisions. Interestingly, they also indicate most strongly that they might become more effective teachers if they participate in instructional improvement activities. Selecting instructional media and grading student performance are of particular interest to agriculture faculty. 
Arts and sciences faculty express more strongly than other groups that evidence of performances, concerts, and other creative activities and professional recognition by outside agencies, groups, or other individuals in the discipline are important in promotion and tenure decisions. They are second only to agriculture in describing the importance of research and awards like research proposal funding. A majority of arts and sciences faculty value supportive incentives like paid released time for professional development, travel funds to attend conferences, one course load reduction, and funds to obtain media and secretarial help. The usefulness of these incentives to encourage their participation in instructional improvement is second only to education.

Predictably, education faculty present the strongest interest in faculty development practices that were not of interest to a majority of the faculty. These include use of a personal computer for wordprocessing and student evaluation, teaching strategies for nontraditional students, group teaching strategies for seminars, use of telecommunication media, and a personal development plan. Education faculty express interest in paid released time for professional development, travel funds to attend conferences, one course load reduction, and funds to obtain media and secretarial help.

Engineering faculty indicate that return to industry or industryeducation exchange is a useful incentive to encourage their participation in instructional improvement. They express particular interest in writing test items and grading student performance.

Faculty in professions which include architecture, business administration, and law strongly indicate that evidence of publication of books and articles is very important in promotion and tenure decisions. They are second only to agriculture in citing its importance. Faculty in professions report interest in writing test items, constructing examinations, and grading student performance.

Although these profiles of faculty are specific to one institution, there are implications for faculty developers at other institutions. The survey process can be used to study faculty attitudes toward instructional improvement on any campus where faculty are expected to teach and engage in scholarly activity. This may provide an indication of incentives to encourage participation in instructional improvement and identify areas of interest. 
Examining faculty opinions as a whole and then by discipline or college is recommended. Specific incentives may be meaningful to faculty in one college eventhough they are not desirable to the faculty as a whole. Likewise, interest in instructional improvement areas may differ among colleges. This information may help faculty developers target their efforts and resources toward receptive faculty.

Further research is needed to determine if faculty opinions are similar on other campuses. This may contribute to creating profiles by disciplines or colleges to identify instructional improvement barriers, incentives, and interests of faculty.

\section{References}

Aitken, N. D., \& Sorcinelli, M. D. (1994). Academic leaders and faculty developers: Creating an institutional culture that values teaching. To Improve the Academy, 13, 63-77.

Angelo, T. A. (1989). Faculty development for learning: The promise of classroom research. To Improve the Academy, 8, 37-60.

Armour, R. A., Fuhrmann, B. S., \& Wergin, J. F. (1990). Senior faculty career attitudes: Implications for faculty development. To Improve the Academy, 9, 217-230.

Diamond, R. M., \& Adam, B. E. (1993). Recognizing faculty work: Reward systems for the year 2000. New Directions for Teaching and Learning, No. 80. San Francisco, CA: Jossey-Bass.

Emery, L. J., \& Hammons, J. O. (1991). Motivating faculty to participate in instructional improvement activities: A case study. Journal of Staff, Program, \& Organization Development, 9(1), 15-27.

Fairweather, J. S. (1993). Faculty rewards reconsidered: The nature of tradeoffs. Change, 25(4), 44-47.

Koontz, H., O’Donnell, C., \& Weihrich, H. (1984). Management (8th ed.). New York: McGraw-Hill.

McKeachie, W. J. (1991). What theories underlie the practice of faculty development? To Improve the Academy, 10, 3-8.

Pinder, C. C. (1984). Work motivation: Theory, issues, and applications. Glenview, IL: Scott-Foresman.

Porter, L., \& Lawler, E. E. (1968). Managerial attitudes and performance. Homewood, IL: Dorsey Press.

Vroom, V. H. (1964). Work and motivation. New York: Wiley.

Weimer, M. (1993). The disciplinary journals on pedagogy. Change, 25(6), 44-51.

Wright, W. A., \& O'Neil, M. C. (1994). Teaching improvement practices: New perspectives. To Improve the Academy, 13, 5-37. 